\title{
The complete chloroplast DNA sequence of the green alga Oltmannsiellopsis viridis reveals a distinctive quadripartite architecture in the chloroplast genome of early diverging ulvophytes
}

\author{
Jean-François Pombert, Claude Lemieux and Monique Turmel*
}

Address: Département de biochimie et de microbiologie, Université Laval, Québec, Canada

Email: Jean-François Pombert - jean-francois.pombert@rsvs.ulaval.ca; Claude Lemieux - claude.lemieux@rsvs.ulaval.ca;

Monique Turmel* - monique.turmel@rsvs.ulaval.ca

* Corresponding author

Published: 03 February 2006

BMC Biology 2006, 4:3 doi:10.1 186/1741-7007-4-3

This article is available from: http://www.biomedcentral.com/l74I-7007/4/3

(c) 2006 Pombert et al; licensee BioMed Central Ltd.

This is an Open Access article distributed under the terms of the Creative Commons Attribution License (http://creativecommons.org/licenses/by/2.0), which permits unrestricted use, distribution, and reproduction in any medium, provided the original work is properly cited.
Received: 17 November 2005

Accepted: 03 February 2006

\begin{abstract}
Background: The phylum Chlorophyta contains the majority of the green algae and is divided into four classes. The basal position of the Prasinophyceae has been well documented, but the divergence order of the Ulvophyceae, Trebouxiophyceae and Chlorophyceae is currently debated. The four complete chloroplast DNA (cpDNA) sequences presently available for representatives of these classes have revealed extensive variability in overall structure, gene content, intron composition and gene order. The chloroplast genome of Pseudendoclonium (Ulvophyceae), in particular, is characterized by an atypical quadripartite architecture that deviates from the ancestral type by a large inverted repeat (IR) featuring an inverted rRNA operon and a small single-copy (SSC) region containing 14 genes normally found in the large single-copy (LSC) region. To gain insights into the nature of the events that led to the reorganization of the chloroplast genome in the Ulvophyceae, we have determined the complete cpDNA sequence of Oltmannsiellopsis viridis, a representative of a distinct, early diverging lineage.
\end{abstract}

Results: The 15I,933 bp IR-containing genome of Oltmannsiellopsis differs considerably from Pseudendoclonium and other chlorophyte cpDNAs in intron content and gene order, but shares close similarities with its ulvophyte homologue at the levels of quadripartite architecture, gene content and gene density. Oltmannsiellopsis cpDNA encodes 105 genes, contains five group I introns, and features many short dispersed repeats. As in Pseudendoclonium cpDNA, the rRNA genes in the IR are transcribed toward the single copy region featuring the genes typically found in the ancestral LSC region, and the opposite single copy region harbours genes characteristic of both the ancestral SSC and LSC regions. The 52 genes that were transferred from the ancestral LSC to SSC region include 12 of those observed in Pseudendoclonium cpDNA. Surprisingly, the overall gene organization of Oltmannsiellopsis cpDNA more closely resembles that of Chlorella (Trebouxiophyceae) cpDNA.

Conclusion: The chloroplast genome of the last common ancestor of Oltmannsiellopsis and Pseudendoclonium contained a minimum of 108 genes, carried only a few group I introns, and featured a distinctive quadripartite architecture. Numerous changes were experienced by the chloroplast genome in the lineages leading to Oltmannsiellopsis and Pseudendoclonium. Our comparative analyses of chlorophyte cpDNAs support the notion that the Ulvophyceae is sister to the Chlorophyceae. 


\section{Background}

The green algae are divided into the phyla Streptophyta and Chlorophyta. The Streptophyta (sensu Bremer [1]) encompasses the algae from the class Charophyceae and all land plants, whereas the Chlorophyta (sensu Sluiman [2]) contains algae from the classes Prasinophyceae, Ulvophyceae, Trebouxiophyceae and Chlorophyceae [3]. The basal position of the Prasinophyceae in the Chlorophyta is generally well established, but the branching order of the Ulvophyceae, Trebouxiophyceae and Chlorophyceae (UTC) remains a matter of debate [4-6]. It has been proposed that a third lineage at the base of the Streptophyta and Chlorophyta is represented by Mesostigma viride [7-9], an alga traditionally classified within the prasinophytes. This green plant lineage, however, is debated, as some studies suggest that Mesostigma is an early offshoot of the phylum Streptophyta [10-12].

Investigations of chloroplast DNA (cpDNA) from green algae representing each of the five recognized classes have revealed that the genomes of the charophyte Chaetosphaeridium globosum [13] and the prasinophytes Mesostigma [7] and Nephroselmis olivacea [14] are highly similar to those of land plants. Like most land plants cpDNAs, these green algal genomes are partitioned into a quadripartite architecture by two copies of a large inverted repeat (IR) separating small (SSC) and large (LSC) single copy regions. Most notably, the great majority of the genes occupying a given single copy region in prasinophyte genomes map to the same single copy region in Chaetosphaeridium and land plant cpDNAs. The increased structural stability of the chloroplast genome conferred by the IR sequence has been hypothesized to limit gene exchanges between the SSC and LSC regions [15]. The IR region readily expands or contracts and thus can easily gain or lose genes from the neighbouring single copy regions through a process known as the ebb and flow [16]. Despite its variable gene content, the IR always features the ribosomal RNA (rRNA) operon (rrs-I(gau)-A(ugc)-rrl-rrf) and this operon is always transcribed toward the SSC region. In addition to their characteristic pattern of gene partitioning, prasinophyte and streptophyte chloroplast genomes share a number of features that were most probably inherited from the progenitor of all green plant cpDNAs. First, they have retained several gene clusters that date back to the cyanobacterial ancestor of all chloroplasts. Second, their genes are densely packed and their intergenic regions virtually lack short dispersed repeats (SDRs). Finally, with 128 to 137 genes, their gene repertoire is one of the largest among green plant cpDNAs.

In contrast, the chloroplast genome has been substantially reorganized in the UTC. The quadripartite architecture has been lost from the genome of the trebouxiophyte Chlorella vulgaris [17] following the disappearance of one copy of the IR sequence. Although the quadripartite architecture has been retained in the genome of the ulvophyte Pseudendoclonium akinetum [6], the IR sequence is atypical in featuring a rRNA operon transcribed towards the LSC region [6]. In addition, the pattern of gene partitioning within the SSC/LSC regions of Pseudendoclonium cpDNA deviates significantly from those found in its prasinophyte and land plant counterparts; the small single copy region of this ulvophyte genome includes 14 genes that are usually located within the LSC region. In the chlorophycean alga Chlamydomonas reinhardtii [18], the two single copy regions are similar in size and the genes are so thoroughly scrambled that no distinction is possible between the SSC and LSC regions. The Chlorella, Pseudendoclonium and Chlamydomonas chloroplast genomes have lost many of the ancestral gene clusters that are shared between Mesostigma and Nephroselmis cpDNAs, feature a reduced gene

Table I: General features of Oltmannsiellopsis and other chlorophyte cpDNAs

\begin{tabular}{|c|c|c|c|c|c|}
\hline Feature & Nephroselmis & Chlorella & Oltmannsiellopsis & Pseudendoclonium & Chlamydomonas \\
\hline \multicolumn{6}{|l|}{ Size (bp) } \\
\hline Total & 200,799 & 150,613 & 151,933 & 195,867 & 203,827 \\
\hline IR & 46,137 & -- a & 18,510 & 6,039 & 22,211 \\
\hline LSC & 92,126 & $-\mathrm{-}^{\mathrm{a}}$ & 33,610 & $|40,9| 4$ & $81,307^{b}$ \\
\hline SSC & 16,399 & $--\mathrm{a}$ & 81,303 & 42,875 & $78,088^{b}$ \\
\hline $\mathrm{A}+\mathrm{T}(\%)$ & 57.9 & 68.4 & 59.5 & 68.5 & 65.5 \\
\hline Coding sequences (\%)c & 68.7 & 60.9 & 59.2 & 62.3 & 50.1 \\
\hline Genes (no.) d & 128 & 112 & 105 & 105 & 94 \\
\hline \multicolumn{6}{|l|}{ Introns (no.) } \\
\hline Group I & 0 & 3 & 5 & 27 & 5 \\
\hline Group II & 0 & 0 & 0 & 0 & 2 \\
\hline
\end{tabular}

a Because Chlorella cpDNA lacks an IR, only the total size of this genome is given.

b The LSC and SSC regions of Chlamydomonas cpDNA cannot be distinguished unambiguously.

c Conserved genes, unique ORFs and introns were considered as coding sequences.

d Genes present in the IR were counted only once. Unique ORFs and intron ORFs were not taken into account. 
content (from 94 genes in Chlamydomonas to 112 genes in Chlorella) compared to prasinophyte and streptophyte genomes, and contain SDRs in their intergenic regions. The low density of coding sequences in these genomes is explained not only by the smaller number of genes but also by the expansion of intergenic regions. Moreover, unlike Mesostigma and Nephroselmis cpDNAs, the chloroplast genomes of the three UTC algae have acquired group I introns (from three in Chlorella to 27 in Pseudendoclonium) and group II introns (two in Chlamydomonas).

To gain insights into the nature of the events that led to the reorganization of the chloroplast genome in the Ulvophyceae, we have determined the complete cpDNA sequence of Oltmannsiellopsis viridis. This marine unicellular green alga exhibits a counterclockwise arrangement of basal bodies $[19,20]$ and a single cup-shaped chloroplast [20]. Previously classified in the Chlorophyceae [19,21], Oltmannsiellopsis is currently considered to be the type species of the order Oltmannsiellopsidales (Ulvophyceae) [22]. The Oltmannsiellopsidales have been shown to branch at the base of the Ulvophyceae [4] and have been used as outgroup for phylogenetic analyses of the Ulvophyceae [23-25]. Considering that Pseudendoclonium represents a distinct, early diverging lineage of the Ulvophyceae (Ulotrichales, see supplementary Figure S1 in [6]), identification of the set of features common to Olt- mannsiellopsis and Pseudendoclonium cpDNAs should throw light into the chloroplast genome architecture of the earliest diverging ulvophytes and, accordingly, into the cpDNA changes that occurred in the separate lineages leading to Oltmannsiellopsis and Pseudendoclonium. We found that the IR-containing genome of Oltmannsiellopsis differs considerably from its Pseudendoclonium and other chlorophyte counterparts in intron content and gene order, but shares closer similarities with Pseudendoclonium cpDNA in terms of quadripartite architecture, gene content and gene density. In the context of the debate concerning the branching order of the UTC lineages, the predicted architecture of the chloroplast genome of the earliest members of the Ulvophyceae strengthens the notion that this lineage is sister to the Chlorophyceae $[5,6]$.

\section{Results and discussion \\ General features}

Table 1 compares the general features of Oltmannsiellopsis cPDNA [GenBank: DQ291132] with those of the four chlorophyte cpDNAs completely sequenced thus far, i.e. the genomes of Nephroselmis [GenBank:NC 000927], Chlorella [GenBank:NC_001865], Pseudendoclonium [GenBank:AY835431] and Chlamydomonas [GenBank:NC 005353]. At 59.5\%, the overall A+T content of Oltmannsiellopsis cpDNA is similar to that of Nephroselmis

Table 2: Differences between the gene repertoires of Oltmannsiellopsis and other UTC algal cpDNAs

\begin{tabular}{|c|c|c|c|c|}
\hline Gene $^{a}$ & Chlorella & Oltmannsiellopsis & Pseudendoclonium & Chlamydomonas \\
\hline$a c c D$ & 0 & $\bullet$ & - & O \\
\hline$c h l B$ & ○ & 0 & O & - \\
\hline chll & 0 & 0 & 0 & 0 \\
\hline chlL & 0 & 0 & $\mathrm{O}$ & 0 \\
\hline $\operatorname{ch} / N$ & 0 & 0 & O & - \\
\hline cysA & 0 & $\mathrm{O}$ & $\mathrm{O}$ & $\mathrm{O}$ \\
\hline cys $T$ & $\bullet$ & ○ & $\bigcirc$ & O \\
\hline infA & 0 & 0 & 0 & 0 \\
\hline $\min D$ & 0 & 0 & 0 & 0 \\
\hline psal & ○ & - & ○ & O \\
\hline psaM & 0 & 0 & 0 & 0 \\
\hline rpl/2 & $\bullet$ & $\bullet$ & $\bullet$ & O \\
\hline rpll9 & 0 & 0 & 0 & O \\
\hline rp/32 & 0 & 0 & 0 & 0 \\
\hline ycf20 & 0 & 0 & 0 & O \\
\hline ycf62 & 0 & $\mathrm{O}$ & 0 & $\mathrm{O}$ \\
\hline $\operatorname{trnL}(\mathrm{caa})$ & 0 & $\mathrm{O}$ & 0 & 0 \\
\hline $\operatorname{trnL}(\mathrm{gag})$ & $\bullet$ & $\bigcirc$ & $\bigcirc$ & $\bigcirc$ \\
\hline $\operatorname{trnR}(\mathrm{ccg})$ & 0 & O & - & O \\
\hline $\operatorname{trnR}(\mathrm{ccu})$ & 0 & 0 & 0 & 0 \\
\hline $\operatorname{trnS}(g g a)$ & $\bullet$ & O & ○ & $\bigcirc$ \\
\hline $\operatorname{trnT}(\mathrm{ggu})$ & 0 & 0 & 0 & 0 \\
\hline
\end{tabular}

a $A$ filled/open circle denotes the presence/absence of a gene. Only the genes that are missing in one or more genomes are indicated. $A$ total of 91 genes are shared by all compared cpDNAs: atpA, B, E, F, H, I, ccsA, cemA, clpP, ftsH, petA, B, D, G, L, psaA, B, C, J, psbA, B, C, D, E, F, H, I, J, K, L, M, N, T, Z, rbcL, rpl2, 5, 14, 16, 20, 23, 36, rpoA, B, CI, C2, rps2, 3, 4, 7, 8, 9, II, I2, I4, I8, 19, rrf, rrl, rrs, tufA, ycfl, 3, 4, I2, trnA(ugc), C(gca), D(guc), $E$ (uuc), $F($ gaa), G(gcc), G(ucc), H(gug), I(cau), I(gau), K(uuu), L(uaa), L(uag), Me(cau), Mf(cau), N(guu), P(ugg), $Q$ (uug), $R$ (acg), $R$ (ucu), $S$ (gcu), $S$ (uga), $T$ (ugu), $V($ uac), $W$ (cca), $Y($ gua). 


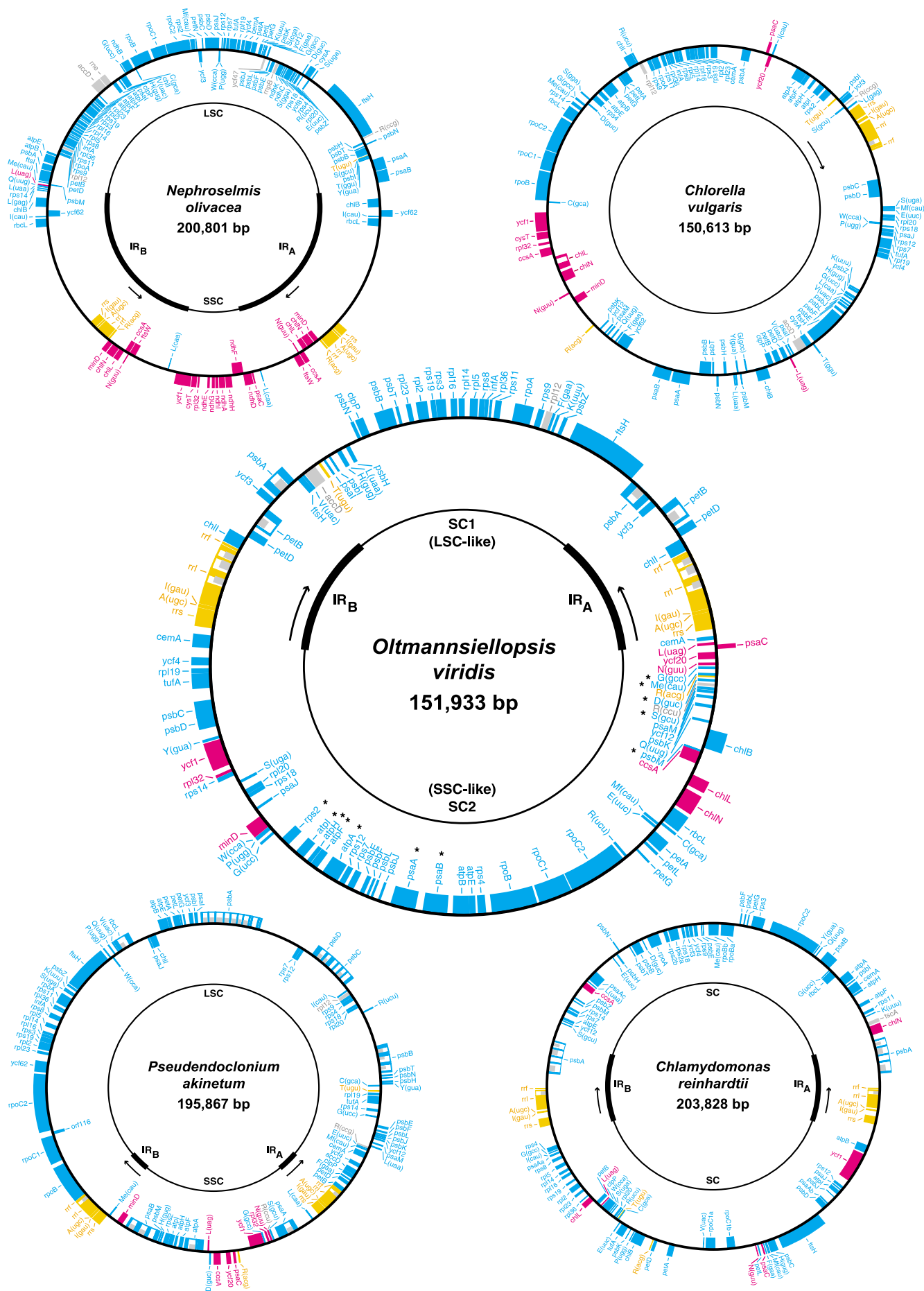

Figure I

Gene maps of Oltmannsiellopsis and other chlorophyte cpDNAs. Genes (filled boxes) outside each map are transcribed clockwise. The transcription direction of the rRNA genes is indicated by arrows. Genes shown in yellow, blue and red map to the IR, LSC and SSC regions in Mesostigma cpDNA, respectively. On the Oltmannsiellopsis map, genes characteristic of the LSC region that reside in the single copy region corresponding to SSC in both Oltmannsiellopsis and Pseudendoclonium cpDNAs are denoted by asterisks. Genes absent from Mesostigma cPDNA are shown in grey. tRNA genes are indicated by the one-letter amino acid code followed by the anticodon in parentheses (Me, elongator methionine; Mf, initiator methionine). A total of five introns (open boxes) were identified, some of which feature ORFs (narrow boxes). 
Table 3: Compared sizes of expanded genes in Oltmannsiellopsis and other UTC algal cpDNAs

\begin{tabular}{|c|c|c|c|c|c|c|c|c|}
\hline \multirow[t]{2}{*}{ Gene } & \multicolumn{2}{|c|}{ Chlorella } & \multicolumn{2}{|c|}{ Oltmannsiellopsis } & \multicolumn{2}{|c|}{ Pseudendoclonium } & \multicolumn{2}{|c|}{ Chlamydomonas } \\
\hline & Size (bp) & Expansion $^{a}$ & Size (bp) & Expansion $^{a}$ & Size (bp) & Expansion $^{a}$ & Size (bp) & Expansion $^{a}$ \\
\hline cemA & 801 & 1.6 & 1059 & 2.2 & 909 & 1.8 & 1503 & 3.0 \\
\hline $\mathrm{ftsH}$ & 5163 & 1.9 & 6879 & 2.6 & 7791 & 2.9 & 8916 & 3.3 \\
\hline$r p o A$ & 837 & 0.9 & 1527 & 1.6 & 1734 & 1.8 & $2213^{b}$ & 2.3 \\
\hline$r p o B$ & 3906 & 1.2 & 4251 & 1.3 & 6537 & 2.0 & $4967^{c}$ & 1.5 \\
\hline rpoCl & 2511 & 1.3 & 3066 & 1.5 & 4737 & 2.4 & $5739 c$ & 2.9 \\
\hline rpoC2 & 4689 & 1.3 & 5580 & 1.5 & 10389 & 2.8 & 9363 & 2.5 \\
\hline ycfl & 2460 & 2.0 & 2427 & 2.0 & 2505 & 2.0 & 5988 & 4.9 \\
\hline
\end{tabular}

a Size relative to the corresponding gene in Mesostigma. Each value was obtained by dividing the size of the UTC algal gene by the size of the Mesostigma gene.

$\mathrm{b}$ The indicated size is derived from our unpublished sequence data. We found that a portion of the $r p o A$ coding sequences is missing in [GenBank:NC 005353] as a result of a sequencing error introducing a frameshift mutation.

' The indicated size includes the intergenic spacer separating the ORFs corresponding to the 5' and $3^{\prime}$ portions of the gene.

cpDNA but is significantly lower than those of the three previously sequenced UTC genomes. The Oltmannsiellopsis genome maps as a circular molecule of 151,933 bp (Figure 1) and contains 105 genes. Two copies of an IR sequence of $18,510 \mathrm{bp}$, each encoding ten genes, are separated from one another by unequal single copy regions, designated SC1 and SC2. Like other UTC cpDNAs, the Oltmannsiellopsis genome is less densely packed with coding sequences than Mesostigma and Nephroselmis cpDNAs; at $59.2 \%$, its density of coding sequences is similar to those of Chlorella and Pseudendoclonium cpDNAs. Intergenic spacers in Oltmannsiellopsis cpDNA feature SDRs and have an average size of $512 \mathrm{bp}$, a value comparable to that observed for Pseudendoclonium cpDNA (600 bp). A total of five introns, all of which belong to the group I family, were identified in Oltmannsiellopsis cpDNA.

\section{Gene and intron contents}

The gene content of Oltmannsiellopsis cpDNA is intermediate between those of Chlorella and Chlamydomonas cpDNAs (Table 1). Although Oltmannsiellopsis and Pseudendoclonium cpDNAs encode the same number of genes, these genomes differ slightly in their gene repertoire (Table 2). Oltmannsiellopsis cpDNA has retained all three chl genes that are missing from Pseudendoclonium cpDNA but has lost $y c f 62, \operatorname{trnL}$ (caa) and $\operatorname{trn} R(\mathrm{ccg})$. Relative to Chlorella cpDNA, the genomes of Oltmannsiellopsis, Pseudendoclonium and Chlamydomonas are missing a set of five genes, i.e. cysA, cyst, and three tRNA genes ( $\operatorname{trn} L(\mathrm{gag})$, $\operatorname{trn} S$ (gga) and $\operatorname{trnT}(\mathrm{ggu}))$ (Table 2). The absence of three genes $(\gamma c f 62, \operatorname{trnL}(\mathrm{caa})$ and $\operatorname{trnR}(\mathrm{ccg}))$ is uniquely shared by Oltmannsiellopsis and Chlamydomonas cpDNAs, whereas no specific gene loss is shared by Pseudendoclonium and Chlamydomonas cpDNAs. Both Oltmannsiellopsis and Pseudendoclonium cpDNAs have retained the $\operatorname{trn} R(\mathrm{ccu})$ gene, which is absent from all other completely sequenced chlorophyte cpDNAs.

As in the UTC chloroplast genomes previously investigated, the coding regions of several genes in Oltmannsiellopsis cpDNA are expanded relative to their Mesostigma counterparts [6] (Table 3). However, most of the gene expansions in Oltmannsiellopsis are less extensive than

Table 4: Group I introns in Oltmannsiellopsis cpDNA

\begin{tabular}{|c|c|c|c|c|c|}
\hline \multirow[b]{2}{*}{ Designation } & \multirow[b]{2}{*}{ Subgroup ${ }^{a}$} & \multirow[b]{2}{*}{ Size (bp) } & \multicolumn{3}{|c|}{ ORF } \\
\hline & & & Location $^{b}$ & Conserved motifc & Size (codons) \\
\hline Ov.petB.I & $\mathrm{IB}$ & 1322 & L8 & LAGLIDADG (2) & 264 \\
\hline Ov.psbA.I & $\mathrm{IA} 2$ & 1127 & L6 & GIY-YIG & 240 \\
\hline Ov.rrl.I & IB4 & 830 & L8 & LAGLIDADG (I) & 167 \\
\hline Ov.rrl.2 & IB4 & 1129 & L9.I & LAGLIDADG (2) & 250 \\
\hline Ov.rrl.3 & IA3 & 767 & L6 & LAGLIDADG (I) & 165 \\
\hline
\end{tabular}

a Introns were classified according to Michel and Westhof [44]. The subcategory of the Ov.petB.I intron could not be identified unambiguously.

b $L$ followed by a number refers to the loop extending the base-paired region identified by the number.

c The conserved motif in the predicted homing endonuclease is given, with the number of copies of the LAGLIDADG motif indicated in parentheses. 
Table 5: Group I introns at identical gene locations in Oltmannsiellopsis cpDNA, other green algal cpDNAs and land plant cpDNAs

\begin{tabular}{|c|c|c|}
\hline \multirow[t]{2}{*}{ Oltmannsiellopsis intron } & \multicolumn{2}{|c|}{ Homologous Intron } \\
\hline & Green planta/Intron numberb & Accession number \\
\hline \multirow[t]{2}{*}{ Ov.psbA.I } & Pseudendoclonium akinetum i5 (U) & [GenBank:AY83543I] \\
\hline & Chlamydomonas reinhardtii i3 (C) & [GenBank:NC 005353] \\
\hline \multirow[t]{14}{*}{ Ov.rrl.I } & Chlamydomonas geitleri (C) & [GenBank:L43353] \\
\hline & Dunaliella parva i2 (C) & [GenBank:L43540] \\
\hline & Haematococcus lacustris i3 (C) & [GenBank:L4915I] \\
\hline & Chlamydomonas callosa i3 (C) & [GenBank:L4350I] \\
\hline & Chlamydomonas komma i2 (C) & [GenBank:L43502] \\
\hline & Chlamydomonas mexicana il (C) & [GenBank:L49|48] \\
\hline & Chlamydomonas frankii i2 (C) & [GenBank:L43352] \\
\hline & Chlamydomonas pallidostigmatica i2 (C) & [GenBank:L43503] \\
\hline & Neochloris aquatica i2 (C) & [GenBank:L49|55] \\
\hline & Chlorosarcina brevispinosa i2 (C) & [GenBank:L49|50] \\
\hline & Pedinomonas tuberculata il (?) & [GenBank:L4354I] \\
\hline & Monomastix species M722 il (P) & [GenBank:L44|24] \\
\hline & Monomastix species OKE-I il (P) & [GenBank:L49|54] \\
\hline & Pterosperma cristatum $(\mathrm{P})$ & [GenBank:L43359] \\
\hline \multirow[t]{13}{*}{ Ov.rrl.2 } & Chlamydomonas monadina i3 (C) & [GenBank:L49|49] \\
\hline & Chlamydomonas humicola (C) & [GenBank:L42989] \\
\hline & Dunaliella parva i4 (C) & [GenBank:L43540] \\
\hline & Chlamydomonas zebra (C) & [GenBank:L43356] \\
\hline & Chlamydomonas starrii (C) & [GenBank:L43504] \\
\hline & Chlamydomonas frankii i4 (C) & [GenBank:L43352 \\
\hline & Neochloris aquatica i3 (C) & [GenBank:L49|55] \\
\hline & Ankistrodesmus stipitatus i2 (C) & [GenBank:L42984] \\
\hline & Stigeoclonium helveticum i4 (C) & [GenBank:L49157] \\
\hline & Trebouxia aggregata i2 $(\mathrm{T})$ & [GenBank:L43542] \\
\hline & Trichosarcina mucosa il (U) & [GenBank:AY00834I] \\
\hline & Pedinomonas tuberculata i3 (?) & [GenBank:L4354I] \\
\hline & Monomastix species OKE-I i3 (P) & [GenBank:L49|54] \\
\hline \multirow[t]{21}{*}{ Ov.rrl.3 } & Chlamydomonas agloeformis (C) & [GenBank:L4335I] \\
\hline & Chlamydomonas callosa i4 (C) & [GenBank:L4350I] \\
\hline & Chlamydomonas iyengarii (C) & [GenBank:L43354] \\
\hline & Chlamydomonas mexicana i2 (C) & [GenBank:L49|48] \\
\hline & Chlamydomonas nivalis (C) & [GenBank:L42990] \\
\hline & Chlamydomonas peterfii (C) & [GenBank:L43538] \\
\hline & Chlamydomonas reinhardtii (C) & [GenBank:NC 005353] \\
\hline & Carteria lunzensis (C) & [GenBank:L42986] \\
\hline & Carteria olivieri (C) & [GenBank:L43500] \\
\hline & Haematococcus lacustris i4 (C) & [GenBank:L49|5I] \\
\hline & Pediastrum biradiatum (C) & [GenBank:L49|56] \\
\hline & Neochloris aquatica i4 (C) & [GenBank:L49|55] \\
\hline & Scenedesmus obliquus (C) & [GenBank:L43360] \\
\hline & Pseudendoclonium akinetum $(\mathrm{U})$ & [GenBank:AY83543I] \\
\hline & Trichosarcina mucosa i2 $(\mathrm{U})$ & [GenBank:AY00834I] \\
\hline & Chlorella vulgaris $(\mathrm{T})$ & [GenBank:NC 001865$]$ \\
\hline & Monomastix species M722 i3 (P) & [GenBank:L44I24] \\
\hline & Monomastix species OKE-I i4 (P) & [GenBank:L49|54] \\
\hline & Scherffelia dubia (P) & [GenBank:L44126] \\
\hline & Anthoceros punctatus (E) & [GenBank:AF393576] \\
\hline & Anthoceros formosae (E) & [GenBank: \\
\hline
\end{tabular}

a The letter in parentheses indicates the specific chlorophyte/streptophyte lineage comprising the green algal/plant indicated. P, Prasinophyceae; U, Ulvophyceae; T, Trebouxiophyceae; C, Chlorophyceae; E, Embryophyta; and ?, uncertain affiliation within the Chlorophyta.

$\mathrm{b}$ The intron number is given when more than one intron is present. 


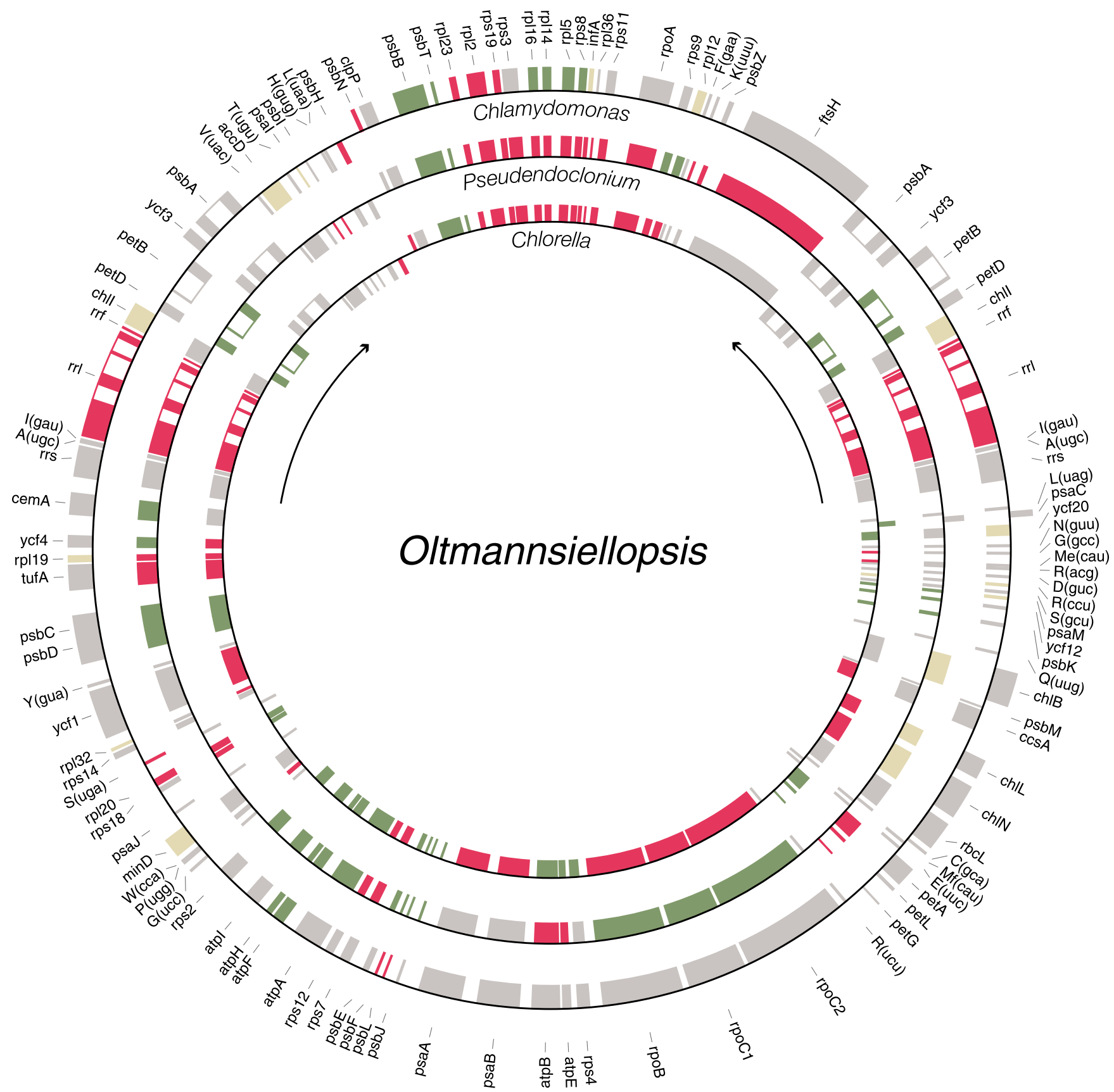

Figure 2

Gene clusters shared between Oltmannsiellopsis and other UTC algal cpDNAs. Shared clusters are shown on the Oltmannsiellopsis gene map as alternating series of green and red boxes. Genes located outside conserved clusters are shown in grey. Genes missing from Chlamydomonas, Pseudendoclonium and Chlorella are represented in beige. The extent of the IR and transcription direction of the rRNA genes are denoted by arrows. Genes outside the map are transcribed clockwise.

those in Pseudendoclonium; only cemA displays a longer coding sequence than its Pseudendoclonium homologue.

Our finding of five group I introns in Oltmannsiellopsis cpDNA contrasts sharply with the 27 group I introns found in Pseudendoclonium cpDNA [6] (Table 1). The lower abundance of introns in Oltmannsiellopsis cpDNA mainly accounts for the smaller size of this genome relative to Pseudendoclonium cpDNA. The Oltmannsiellopsis introns interrupt three genes ( $p e t B, p s b A$, and $r r l$ ) found in the IR (Table 4). The pet $B$ and $p s b A$ genes each contain one intron, whereas three introns are present in $\mathrm{rrl}$. All five 


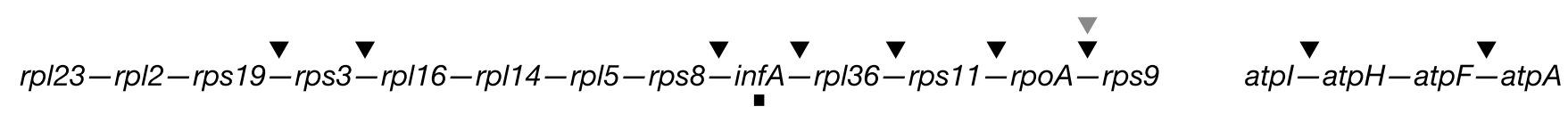
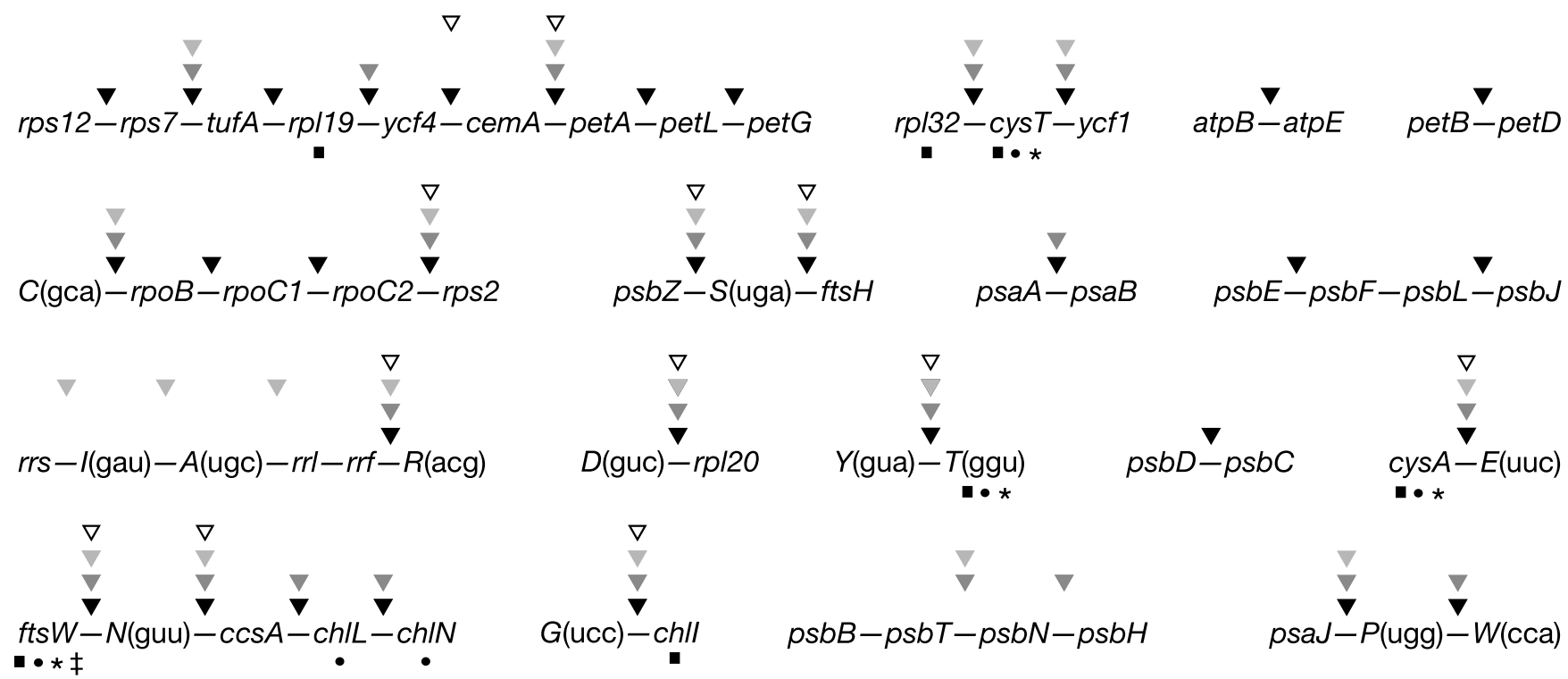

\section{Figure 3}

Fragmented ancestral gene clusters in the cPDNAs of UTC algae. The indicated clusters are found in both Mesostigma and Nephroselmis cpDNAs. Note that rpl22 has not been represented in the large ribosomal protein cluster because it is present only in Mesostigma cpDNA (between rps 19 and rps3). Sites of fragmentation are denoted by arrowheads of different shades above the clusters: Chlamydomonas, filled arrowheads; Pseudendoclonium, dark grey arrowheads; Oltmannsiellopsis, light grey arrowheads; and Chlorella, open arrowheads. Genes missing from Chlamydomonas, Pseudendoclonium, Oltmannsiellopsis and Chlorella are indicated by squares, circles, asterisks and double dagger, respectively. Gene polarities are not shown.

introns, with the exception of the petB intron, are positionally and structurally homologous to previously reported introns in green plant cpDNAs (Table 5). While homologues of the Oltmannsiellopsis psbA intron are present in Pseudendoclonium and Chlamydomonas, homologues of the three $\mathrm{rrl}$ introns are found in a larger diversity of green plants. Considering that these homologous introns have been identified in UTC lineages, they could have been inherited by vertical inheritance from the last common ancestor of UTC algae; however, the finding that they potentially code for homing endonucleases of the LAGLIDADG or GIY-YIG families (Table 4) does not allow us to exclude the possibility that they were acquired by horizontal transfer. Although most of the 16 group I introns in Pseudendoclonium cpDNA have no homologues at identical cognate sites in other chloroplast genomes, their close structural and sequence similarities together with their absence from Oltmannsiellopsis cpDNA suggest that they arose from intragenomic proliferation in the lineage leading to Pseudendoclonium [6]. Note that Blast searches of the Oltmannsiellopsis petB intron sequence against the GenBank database failed to detect any homologous intron in other organisms.

\section{Genome structure and gene partitioning}

The pattern of gene partitioning within the single copy regions of Oltmannsiellopsis cpDNA differs substantially from the ancestral partitioning pattern observed for Mesostigma, Nephroselmis and streptophyte cpDNAs (Figure 1 ). The great majority of the 30 genes found in the SC1 region of Oltmannsiellopsis are typically found in the ancestral LSC region, whereas the SC2 region contains 52 genes characteristic of the ancestral LSC region in addition to ten genes characteristic of the ancestral SSC region. Interestingly, SC2 includes 12 of the 14 LSC genes that have been transferred to the SSC region in Pseudendoclonium cpDNA. The two exceptional Pseudendoclonium genes that have no homologues in Oltmannsiellopsis SC2 are $\operatorname{trnH}$ (gug) and $\operatorname{trnL}$ (caa); the $\operatorname{trn} H$ (gug) gene resides in the SC1 region of Oltmannsiellopsis, whereas $\operatorname{trnL}$ (caa) has been lost from Oltmannsiellopsis cpDNA. Considering the gene contents of the Oltmannsiellopsis single copy regions, 


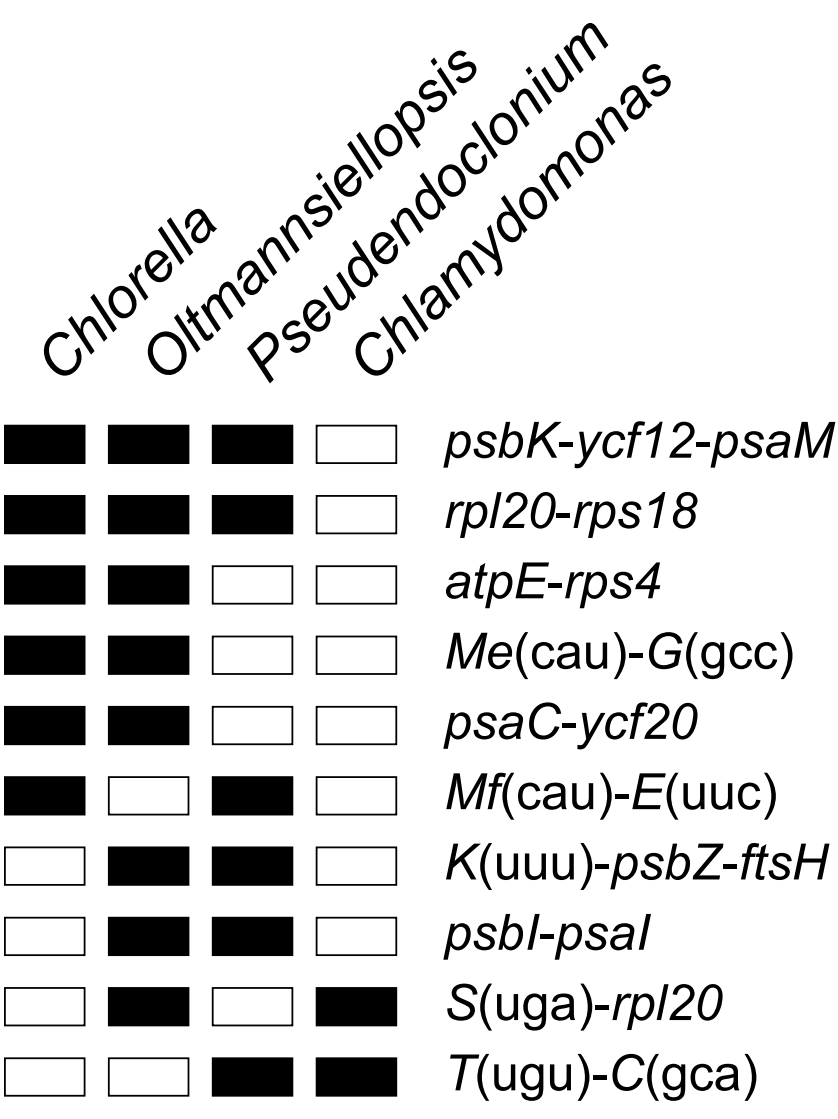

Figure 4

Derived gene clusters shared between the cpDNAs of UTC algae. Filled/open boxes represent the presence/ absence of clusters. Gene polarities are not shown.

it appears inappropriate to label these regions according to their sizes. Although SC1 is smaller than SC2, it likely corresponds to the ancestral LSC region, and SC2 is apparently derived from the ancestral SSC region.

The IR sequence in Oltmannsiellopsis cpDNA is about 12 kb larger than that in Pseudendoclonium cpDNA and contains five genes in addition to those found in the rRNA operon (Figure 1). At 18,510 bp, the IR sequence of Olt- mannsiellopsis is similar in size to that of Chlamydomonas (Table 1). Both IR junctions in Oltmannsiellopsis cpDNA encompass genes (cemA and $f t s H$ ) of which the coding sequences expand into the single copy regions. As in the Pseudendoclonium IR, the Oltmannsiellopsis rRNA genes are transcribed towards the single copy region carrying the genes that map to the LSC in prasinophyte and streptophyte cpDNAs. In contrast, the rRNA operon is transcribed toward the SSC region in Nephroselmis and streptophyte cpDNAs. The orientation of the rRNA operon cannot be established in Chlamydomonas cpDNA owing to the extensively scrambled single copy regions, and this orientation remains unknown in Chlorella cPDNA because of the IR loss.

Considering that Olmannsiellopsis and Pseudendoclonium represent distinct, early diverging lineages of the Ulvophyceae, the striking similarities between the quadripartite architectures of Oltmannsiellopsis and Pseudendoclonium cpDNAs suggest that both the atypical gene partitioning pattern and unusual orientation of the IR were characteristic of the chloroplast genome of earliest-diverging ulvophytes. Our data predict that the SSC region of the last common ancestor of Oltmannsiellopsis and Pseudendoclonium cpDNAs featured 12 of the genes usually found in the LSC region in Nephroselmis and streptophyte cpDNAs, whereas the LSC region contained exclusively genes characteristic of the ancestral LSC region. Consequently, in the lineage leading to Pseudendoclonium, two extra genes were transferred to the SSC region, whereas 40 additional genes migrated to this region in the Oltmannsiellopsis lineage. Although the mechanisms underlying these gene migrations between single copy regions remain unknown, they probably involved intramolecular or intermolecular recombination events. The analysis of conserved gene clusters reported below clearly indicates that several genes were transferred together in the course of these migrations.

Genes have been more extensively shuffled between the two single copy regions in Chlamydomonas cpDNA (Figure 1). It can be envisioned that during the evolution of ulvophytes and chlorophycean green algae, the ancestral pat-

Table 6: Minimal numbers of inversions accounting for gene rearrangements between green algal cpDNAs

\begin{tabular}{|c|c|c|c|c|c|}
\hline \multirow[t]{2}{*}{ Compared cpDNA } & \multicolumn{5}{|c|}{ Number of inversions ${ }^{a}$} \\
\hline & Mesostigma & Nephroselmis & Chlorella & Oltmannsiellopsis & Pseudendoclonium \\
\hline Chlamydomonas & 75 & 74 & 75 & 75 & 77 \\
\hline Pseudendoclonium & 54 & 55 & 52 & 55 & \\
\hline Oltmannsiellopsis & 54 & 55 & 50 & & \\
\hline Chlorella & 46 & 47 & & & \\
\hline Nephroselmis & 43 & & & & \\
\hline
\end{tabular}

a Numbers of gene permutations by inversions were computed using GRIMM. 


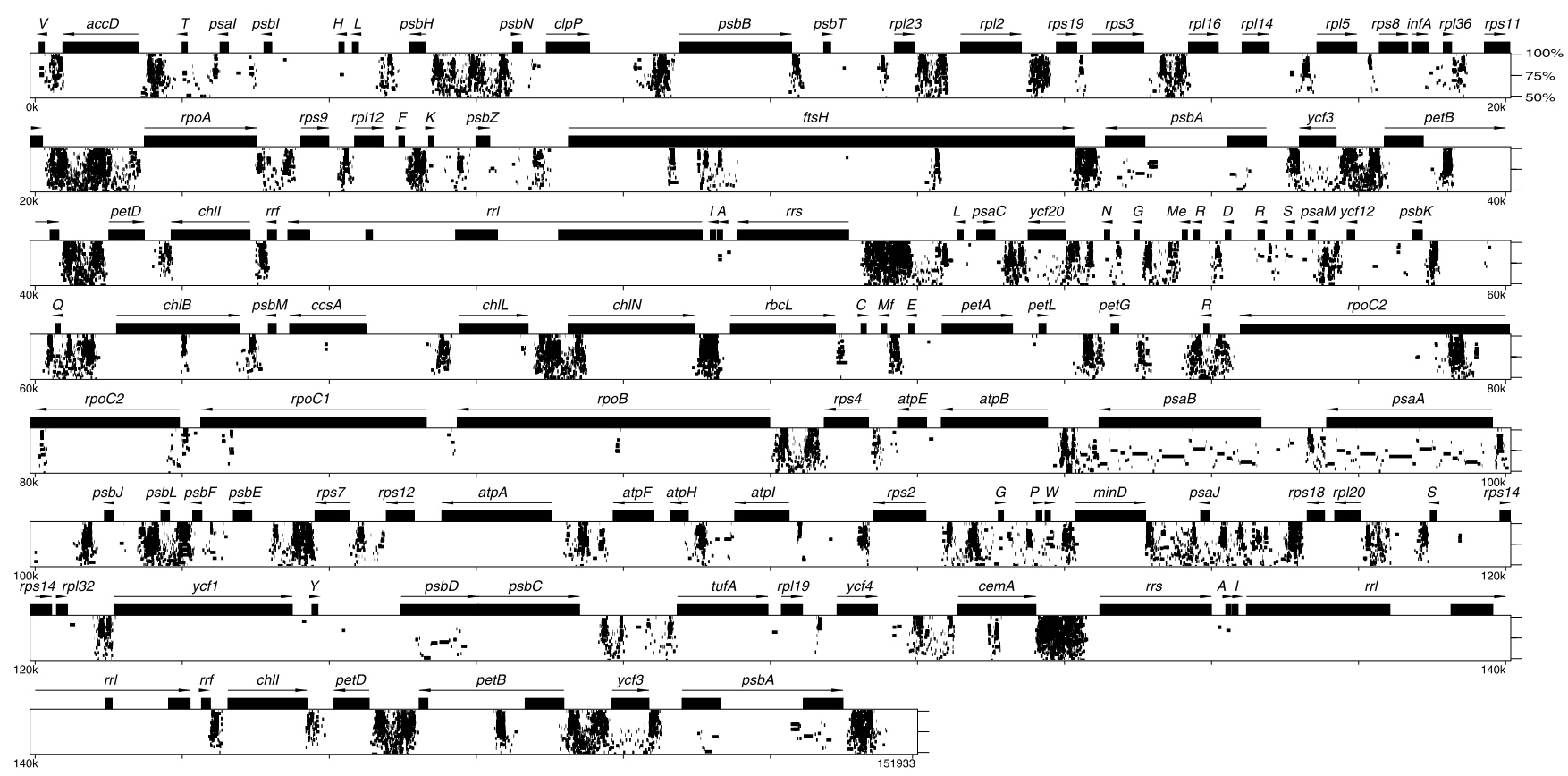

Figure 5

Positions of SDR elements in Oltmannsiellopsis cpDNA. The Oltmannsiellopsis cpDNA sequence was aligned against itself using PipMaker. Regions containing SDRs can be identified as clusters of dots. Similarities between aligned regions are shown as average percent identity (between 50 and 100\% identity). Genes and their polarities are denoted by horizontal arrows and coding sequences are represented by filled boxes.

tern of gene partitioning was disrupted in successive steps, with a Pseudendoclonium-like organization evolving into an Oltmannsiellopsis-like organization, leading ultimately to the extensive scrambling of genes observed in Chlamydomonas. Given the absence of the IR from the Chlorella genome, it is very difficult to ascertain whether the transcription direction of the rRNA operon changed and whether genes were relocated from one genomic region to another during the evolution of trebouxiophytes. Loss of the IR is usually associated with many gene rearrangements [15]; in the case of Chlorella cpDNA, however, all the genes usually found in the ancestral SSC region have remained clustered, with the exception of three genes ( $p s a C, y c f 20$ and $\operatorname{trnL}(\mathrm{uag})$ ) (Figure 1). Investigations of IR-containing chloroplast genomes from distinct trebouxiophyte lineages will be required to test whether some of the gene relocations identified here in both Oltmannsiellopsis and Pseudendoclonium cpDNAs originated from the common ancestor of UTC algae.

\section{Gene clustering}

The overall gene organization of Oltmannsiellopsis cpDNA differs extensively from that of its Pseudendoclonium homologue and, surprisingly, more closely resembles that of Chlorella cpDNA (Figure 2). Oltmannsiellopsis and Chlo- rella cpDNAs share 21 blocks of colinear sequences that contain a total of 65 genes, whereas Oltmannsiellopsis and Pseudendoclonium cpDNAs have in common 18 blocks containing 55 genes. Only eight blocks containing 19 genes are conserved in the Oltmannsiellopsis and Chlamydomonas genomes.

Many of the 24 ancestral gene clusters shared by Mesostigma and Nephroselmis cpDNAs have been disrupted during the evolution of the UTC green algae. In this study, we have analyzed 19 ancestral clusters; the five remaining ones could not be investigated because the genes they contain have been lost from UTC cpDNAs (Figure 3). All 19 clusters have been broken at least in one occasion during the evolution of the UTC algae. With only 12 breakpoints, Chlorella cpDNA displays the strongest conservation of ancestral clusters. With 20 breakpoints, Oltmannsiellopsis cpDNA occupies a median position between Chlorella and Pseudendoclonium (24 breakpoints) cpDNAs, whereas Chlamydomonas cpDNA reveals twice as many breakpoints (42 breakpoints). The Chlamydomonas, Oltmannsiellopsis and Pseudendoclonium genomes share five breakpoints that are missing in Chlorella cpDNA. Aside from these breakpoints, Pseudendoclonium and Chlamydomonas cpDNAs share six breakpoints that are 
Table 7: SDR units in Oltmannsiellopsis cpDNA

\begin{tabular}{lllll}
\hline & & & Number $^{\mathbf{a}}$ \\
\cline { 3 - 4 } Designation & Size (bp) & Sequence & $\mathbf{1 0 0 \%}$ & $\mathbf{9 0 \%}$ \\
\hline A & 11 & CAACACTYCCA & 252 & 426 \\
B & 11 & AWAGCGAAGCW & 89 & 126 \\
C & 7 & GCCCCCC & 126 & 126 \\
D & 8 & GGGGAGGG & 45 & 45 \\
E & 21 & AGGGGCTTTGCTTCGC & 17 & 17 \\
& & GGTTT & & \\
\hline
\end{tabular}

a Numbers of SDR units were determined in searches performed using $100 \%$ or $90 \%$ sequence identity. The genomic locations of these repeated elements are reported in [GenBank: DQ291/32].

absent from Oltmannsiellopsis and Chlorella cpDNAs. There is no breakpoint exclusive to the Oltmannsiellopsis and Chlamydomonas genomes.

Two ancestral clusters display breakpoints that are unique to the Ulvophyceae. The almost universally conserved $p s b B-p s b T-p s b N-p s b H$ cluster was fragmented at the 5 ' end of $p s b N$, creating two separate pieces, each encoding a pair of genes, in Oltmannsiellopsis cpDNA. In the Pseudendoclonium lineage, the introduction of an additional breakpoint on the opposite side of $p s b N$ led to the relocation of this gene on the DNA strand encoding $p s b B$, $p s b T$ and $p s b H$, without any change in gene order. In the Oltmannsiellopsis lineage, three breakpoints occurred in the ancestral rRNA operon to generate a new transcription unit in which the order of the $\operatorname{trn} A(\mathrm{ugc})$ and $\operatorname{trnI}(\mathrm{gau})$ genes has been reversed. Rearranged rRNA operons have been reported for the cpDNAs of the trebouxiophyte Chlorella ellipsoidea [26] and the ulvophyte Codium fragile [27]; however, in these cases, the ancestral rRNA operon was split into separate fragments that are transcribed from different promoters.

In terms of derived gene clusters, Oltmannsiellopsis cpDNA is most similar to Chlorella cpDNA (Figure 4). A derived cluster is defined here as a group of genes with the same relative polarities in two or more UTC genomes, but absent from Mesostigma and Nephroselmis cpDNAs. Oltmannsiellopsis cpDNA shares five derived clusters with its Chlorella homologue, whereas Pseudendoclonium cpDNA shares three clusters, one of which is missing from Oltmannsiellopsis. Of the four derived clusters common to Oltmannsiellopsis and Pseudendoclonium cpDNAs, none is found in Chlamydomonas cpDNA.

We estimated that a minimum of 50 inversions would be required to transform the gene organization of Oltmannsiellopsis cpDNA into that of any other chlorophyte genome (Table 6). Comparative analyses of cpDNAs from land plants [15] and from closely related chlamydomonads $[28,29]$ suggest that inversions represent the predom- inant mechanism of chloroplast genome rearrangements in green plants. However, inversions might be not the only mutational events causing gene order changes in chlorophytes cpDNAs, as transpositions have been proposed to account for some of the rearrangements observed in Campanulaceae [30] and in subclover [31] cpDNAs.

\section{Repeated elements}

A large number of SDR elements are found in Oltmannsiellopsis cpDNA (Figure 5). Although these elements reside predominantly within intergenic spacers and introns, a few copies populate the coding regions of $\operatorname{cem} A, \operatorname{chlB}, \mathrm{chlL}$, chlN, ftsH, rpoB, rpoC1 and rpoC2. The most abundant elements can be classified into five groups of non-overlapping repeat units (A through $\mathrm{E}$ ) on the basis of their primary sequences (Table 7 ). Their sizes range from 7-21 bp and their copy numbers vary from 17 to more than 250. The sequence of repeat unit A or B is most often linked to the reverse complement of the same sequence, thus forming perfect palindromes or putative stem-loop structures with a loop of two A or two T (Figure 6). In some instances, the palindromes or stem portions of the stem-loop structures are extended by the addition of less frequent repeats. Furthermore, a few copies of repeat units A and B occur as solitary sequences, representing probably degenerated versions of the more common arrangements featuring palindromes or stem-loop structures. Repeat unit C can form stem-loop structures, with a loop of variable size. Although repeat units D and E are not associated with stem-loop structures, they reside in the vicinity of other repeated elements.

The SDRs in Oltmannsiellopsis cpDNA do not closely resemble those present in other UTC cpDNAs. The Oltmannsiellopsis repeats are biased in $\mathrm{G}+\mathrm{C}$, whereas the Chlorella repeats show a bias in $\mathrm{A}+\mathrm{T}$. The Pseudendoclonium and Chlamydomonas SDRs are also rich in $\mathrm{G}+\mathrm{C}$, but their sequences share no obvious similarities with the Oltmannsiellopsis repeats. This lack of sequence similarities between SDRs derived from distinct UTC genomes 


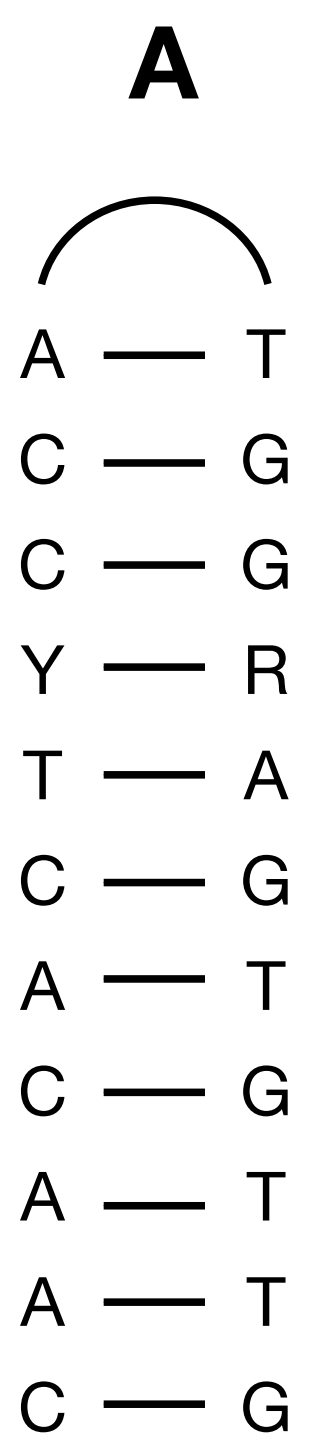

Figure 6

Predicted secondary structures formed by SDR units $A$ and $B$ in Oltmannsiellopsis cpDNA.

suggests that SDRs have been acquired independently in UTC lineages. However, the alternative hypothesis that SDRs were transmitted vertically cannot be excluded if we assume that these elements evolve at a very fast pace. Studies of cpDNAs from closely related UTC taxa will be required to distinguish between these two hypotheses.

SDRs have most probably played a major role in remodelling the chloroplast genome in UTC lineages. A correlation has been previously observed between the abundance of SDRs and the extent of gene rearrangements in UTC algal genomes [6]. This correlation still holds with the addition of Oltmannsiellopsis chloroplast genome sequence. The abundance of SDR elements in Oltmannsiellopsis cpDNA is comparable to that observed in Pseudendo- clonium cpDNA (Figure 7) and genes have been rearranged to a similar extent in both genomes (Table 6). SDRs in green plant cpDNAs could serve as hot spots for nonhomologous recombinational events and lead to inversions and transpositions $[15,30,31]$.

\section{Conclusion}

Although the Oltmannsiellopsis chloroplast genome differs considerably from its Pseudendoclonium counterpart at the levels of intron content and gene order, the two ulvophyte genomes share similarities in gene content and quadripartite architecture. We conclude that the chloroplast genome of the last common ancestor of Oltmannsiellopsis and Pseudendoclonium contained a minimum of 108 genes, was loosely packed with coding sequences, carried only a few group I introns, and featured a quadripartite architecture that deviates from the ancestral type displayed by Mesostigma and Nephroselmis cpDNAs with regard to the transcription direction of the rRNA genes and the gene contents of the single copy regions. Given the phylogenetic positions of Oltmannsiellopsis and Pseudendoclonium, these genomic characters were undoubtedly present in the earliest-diverging members of the Ulvophyceae. Numerous changes were experienced by the chloroplast genome in the lineages leading to Oltmannsiellopsis and Pseudendoclonium; these include contraction/ expansion of the IR, migration of genes from the ancestral LSC region toward the single copy region corresponding to the SSC, gene losses, intron gains/losses, and gene rearrangements within the IR and each of the single copy regions. Considering that the chloroplast genome of Codium fragile (Ulvales) is greatly reduced in size (only 89 kbp) and lacks an IR [27], many additional chloroplast gene losses and rearrangements probably occurred in some lineages of the Ulvophyceae.

Our comparative analysis of the Oltmannsiellopsis chloroplast genome with its chlorophyte counterparts strengthens the idea that the chloroplast genomes of earlydiverging ulvophytes occupy an intermediate position between those of the trebouxiophyte Chlorella and the chlorophycean green alga Chlamydomonas with respect to the retention of ancestral features [6]. In the context of the debate on the branching order of UTC lineages [4-6], this analysis provides further support for the published phylogenetic analysis of mitochondrial gene sequences identifying the Trebouxiophyceae as a basal lineage relative to the Ulvophyceae and Chlorophyceae [5].

\section{Methods}

Isolation and sequencing of Oltmannsiellopsis cpDNA

Oltmannsiellopsis viridis was obtained from the National Institute for Environmental Studies of Japan (NIES 360) and grown in K medium [32] under 12 h light/dark cycles. Organellar DNA was isolated and sequenced as described 

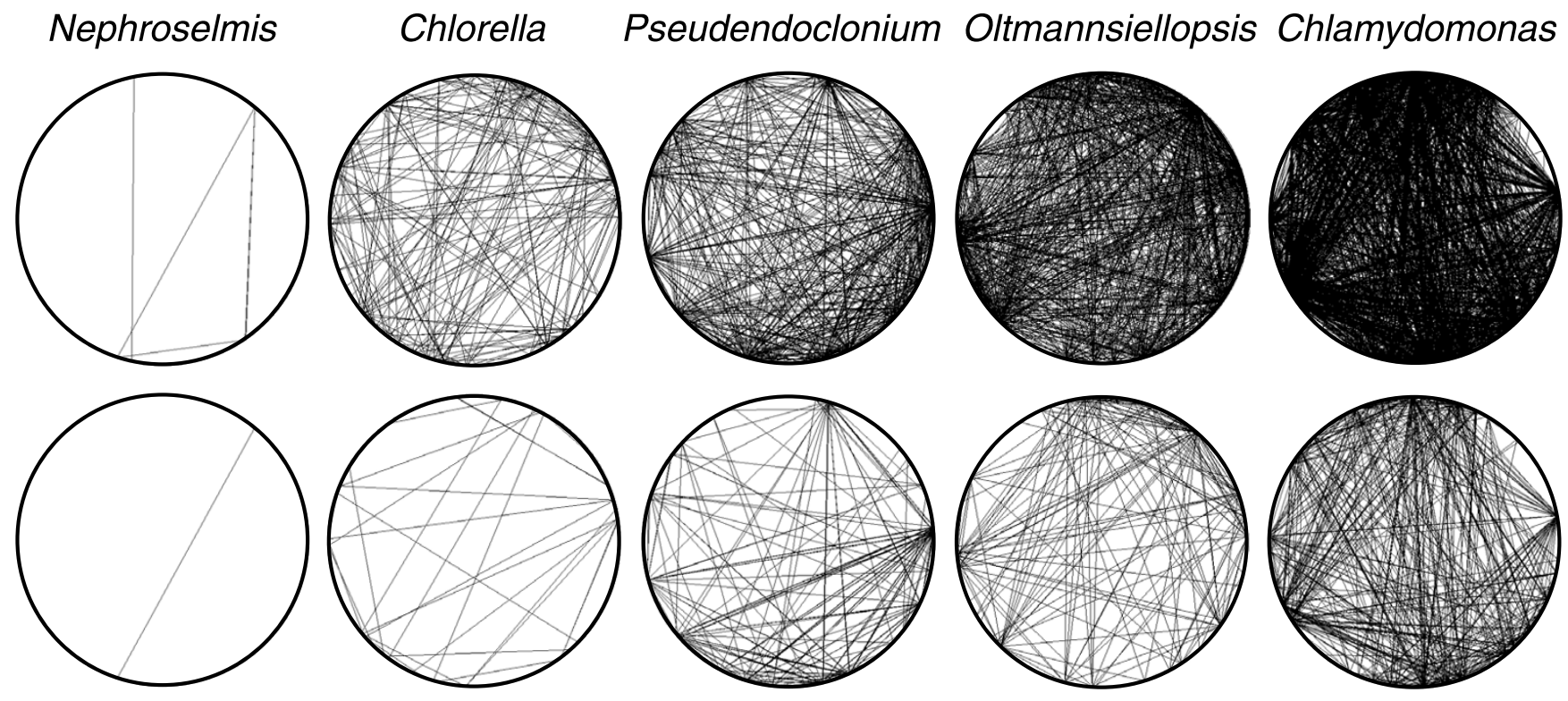

Figure 7

Densities of SDR elements in Oltmannsiellopsis and other chlorophyte cpDNAs as revealed by REPuter.

Repeated elements with identical sequences are connected on the circular representations of the genomes. Repeats larger than $30 \mathrm{bp}$ and $45 \mathrm{bp}$ are shown on the top and bottom panels, respectively. For these analyses, one copy of the IR sequence was deleted from the Nephroselmis, Pseudendoclonium, Oltmannsiellopsis and Chlamydomonas genomes.

previously [5]. Sequences were edited and assembled with SEQUENCHER 4.2.1 (GeneCodes, Ann Arbor, MI). The fully annotated chloroplast genome sequence has been deposited in [GenBank:DQ291132].

\section{Sequence analyses}

Genes and ORFs were identified as described previously [6]. Homologous introns were detected by BLASTN searches [33] against the non-redundant database of National Center for Biotechnology Information using an $E$ value threshold of $1 \times 10^{-4}$. Homologous introns inserted at identical positions within the same gene were identified by manual screening of the GOBASE database [34].

Repeated sequences were mapped with PipMaker [35], identified with REPuter 2.74 [36] and classified with REPEATFINDER [37], using the default parameters. Sequences clustered with REPEATFINDER were aligned manually using BIOEDIT 7.0.1 [38], and non-overlapping SDR units were identified by manual screening of the alignment. Numbers of SDR units were determined with FINDPATTERNS of the GCG Wisconsin Package version 10.2 (Accelrys, Burlington, Mass.), using $100 \%$ or $90 \%$ sequence identity. Putative stem-loop structures and degenerate repeats were identified using PALINDROME and ETANDEM in EMBOSS 2.9.0 [39], respectively. The density of repeated elements in a given chloroplast genome was assessed with REPuter 2.74 [36] using the $-\mathrm{f}$ (forward), -p (palindromic), and -allmax options at minimum lengths (-1) of $30 \mathrm{bp}$ and $45 \mathrm{bp}$. For the analyses involving IR-containing genomes, one copy of the IR sequence was deleted. Circle graphs generated by REPuter were screen-captured at $300 \mathrm{dpi}$ and converted to black and white illustrations with GIMP 2.0 [40]. Repeated elements in different cpDNAs were compared using Vmatch [41] and GenAlyzer $0.81 \mathrm{~b}$ [42].

The GRIMM web server [43] was used to infer the minimal number of gene permutations by inversions in pairwise comparisons of chloroplast genomes. Because GRIMM cannot deal with duplicated genes and requires that the compared genomes have the same gene content, genes within one of the two copies of the IR were excluded and only the genes common to all the compared genomes were analysed. The data set used in the comparative analyses reported in Table 6 contained 90 genes; the three exons of the trans-spliced $p s a A$ gene were coded as distinct fragments (for a total of 92 gene loci).

\section{Abbreviations}

cpDNA, chloroplast DNA; IR, inverted repeat; LSC, large single copy; ORF, open reading frame; rRNA, ribosomal rRNA; SDR, short dispersed repeat; SSC, small single copy; UTC, Ulvophyceae/Trebouxiophyceae/Chlorophyceae. 


\section{Authors' contributions}

JFP participated in the conception of this study, carried out the genome sequencing, performed all sequence analyses, annotated the genome, generated the figures, and drafted the manuscript. CL and MT conceived the study, contributed to the interpretation of the data, and helped to prepare the manuscript. All authors read and approved the final manuscript.

\section{Acknowledgements}

We are grateful to Charles O'Kelly for his valuable suggestions of candidate taxa for this study, to Patrick Charlebois for his help with the analysis of conserved gene clusters, and to Philippe Beauchamp for his technical assistance in determining the Oltmannsiellopsis cpDNA sequence. We also thank Christian Otis for critical reading of the manuscript. This work was supported by a grant from the Natural Sciences and Engineering Research Council of Canada (to MT and CL).

\section{References}

I. Bremer K: Summary of green plant phylogeny and classification. Cladistics 1985, I:369-385.

2. Sluiman HJ: The green algal class Ulvophyceae. An ultrastructural survey and classification. Crypt Bot 1989, 1:83-94.

3. Lewis LA, McCourt RM: Green algae and the origin of land plants. Am / Bot 2004, 9 I ( I 0): I535-1556.

4. Friedl T, O'Kelly CJ: Phylogenetic relationships of green algae assigned to the genus Planophila (Chlorophyta): evidence from I 8S rDNA sequence data and ultrastructure. EurJ Phycol 2002, 37:373-384.

5. Pombert JF, Otis C, Lemieux C, Turmel M: The complete mitochondrial DNA sequence of the green alga Pseudendoclonium akinetum (Ulvophyceae) highlights distinctive evolutionary trends in the Chlorophyta and suggests a sister-group relationship between the Ulvophyceae and Chlorophyceae. Mol Biol Evol 2004, 2 I (5):922-935.

6. Pombert JF, Otis C, Lemieux C, Turmel M: The Chloroplast Genome Sequence of the Green Alga Pseudendoclonium akinetum (Ulvophyceae) Reveals Unusual Structural Features and New Insights into the Branching Order of Chlorophyte Lineages. Mol Biol Evol 2005, 22(9): 1903-1918.

7. Lemieux C, Otis C, Turmel M: Ancestral chloroplast genome in Mesostigma viride reveals an early branch of green plant evolution. Nature 2000, 403(6770):649-652.

8. Turmel M, Ehara M, Otis C, Lemieux C: Phylogenetic relationships among Streptophytes as inferred from chloroplast small and large subunit rRNA gene sequences. J Phycol 2002, 38:364-375.

9. Turmel M, Otis C, Lemieux C: The complete mitochondrial DNA sequence of Mesostigma viride identifies this green alga as the earliest green plant divergence and predicts a highly compact mitochondrial genome in the ancestor of all green plants. Mol Biol Evol 2002, I 9(I):24-38.

10. Bhattacharya D, Weber K, An SS, Berning-Koch W: Actin phylogeny identifies Mesostigma viride as a flagellate ancestor of the land plants. J Mol Evol 1998, 47(5):544-550.

II. Marin B, Melkonian M: Mesostigmatophyceae, a new class of streptophyte green algae revealed by SSU rRNA sequence comparisons. Protist 1999, 150(4):399-4I7.

12. Karol KG, McCourt RM, Cimino MT, Delwiche CF: The closest living relatives of land plants. Science 200I, 294:235I-2353.

13. Turmel M, Otis C, Lemieux C: The chloroplast and mitochondrial genome sequences of the charophyte Chaetosphaeridium globosum: insights into the timing of the events that restructured organelle DNAs within the green algal lineage that led to land plants. Proc Natl Acad Sci USA 2002, 99( I7): I I 275- I I 280.

14. Turmel M, Otis C, Lemieux C: The complete chloroplast DNA sequence of the green alga Nephroselmis olivacea: insights into the architecture of ancestral chloroplast genomes. Proc Natl Acad Sci USA 1999, 96( ( 8): 10248-10253.
15. Palmer JD: Plastid chromosomes: structure and evolution. In The Molecular Biology of Plastids Cell Culture and Somatic Cell Genetics of Plants Volume 7A. Edited by: Bogorad L, Vasil I. San Diego: Academic Press; 1991:5-53.

16. Goulding SE, Olmstead RG, Morden CW, Wolfe KH: Ebb and flow of the chloroplast inverted repeat. Mol Gen Genet 1996, 252(I2):195-206.

17. Wakasugi T, Nagai T, Kapoor M, Sugita M, Ito M, Ito S, Tsudzuki J, Nakashima K, Tsudzuki T, Suzuki Y, Hamada A, Ohta T, Inamura A, Yoshinaga $K$, Sugiura M: Complete nucleotide sequence of the chloroplast genome from the green alga Chlorella vulgaris: the existence of genes possibly involved in chloroplast division. Proc Natl Acad Sci USA 1997, 94(I I):5967-5972.

18. Maul JE, Lilly JW, Cui L, dePamphilis CW, Miller W, Harris EH, Stern DB: The Chlamydomonas reinhardtii plastid chromosome: islands of genes in a sea of repeats. Plant Cell 2002, I4(I I):2659-2679.

19. Chihara M, Inouye I, Takahata N: Oltmannsiellopsis, a new genus of marine flagellate (Dunaliellaceae, Chlorophyceae). Arch Protistenkd 1986, I 32:3 I3-324.

20. Lokhorst GM, Star W: The flagellar apparatus in the marine flagellate algal genus Oltmannsiellopsis (Dunaliellales, Chlorophyceae). Arch Protistenkd 1993, 143:13-32.

21. Hargraves PE, Steele RL: Morphology and ecology of Oltmannsiella virida, sp. nov. (Chlorophyceae: Volvocales). Phycologia 1980, 19:96-102.

22. Nakayama T, Watanabe S, Inouye I: Phylogeny of wall-less green flagellates inferred from I8S rDNA sequence data. Phycological Research 1996, 44:|5|-161.

23. O'Kelly CJ, Wysor B, Bellows WK: Gene sequence diversity and the phylogenetic position of algae assigned to the genera Phaeophila and Ochlochaete (Ulvophyceae, Chlorophyta). J Phycol 2004, 40:789-799.

24. O'Kelly C], Wysor B, Bellows WK: Collinsiella (Ulvophyceae, Chlorophyta) and other ulotrichalean taxa with shell-boring sporophytes form a monophyletic clade. Phycologia 2004, 43(I):4|-49.

25. O'Kelly CJ, Bellows WK, Wysor B: Phylogenetic position of Bolbocoleon piliferum (Ulvophyceae, Chlorophyta): Evidence from reproduction, zoospore and gamete ultrastructure, and small subunit rRNA gene sequences. J Phycol 2004, 40:209-222.

26. Yamada T, Shimaji M: Splitting of the ribosomal RNA operon on chloroplast DNA from Chlorella ellipsoidea. Mol Gen Genet 1987, 208(3):377-383.

27. Manhart JR, Kelly K, Dudock BS, Palmer JD: Unusual characteristics of Codium fragile chloroplast DNA revealed by physical and gene mapping. Mol Gen Genet 1989, 216(2-3):4|7-42I.

28. Boudreau $E$, Turmel $M$ : Gene rearrangements in Chlamydomonas chloroplast DNAs are accounted for by inversions and by the expansion/contraction of the inverted repeat. Plant Mol Biol 1995, 27(2):35I-364.

29. Boudreau $E$, Turmel $M$ : Extensive gene rearrangements in the chloroplast DNAs of Chlamydomonas species featuring multiple dispersed repeats. Mol Biol Evol 1996, I3(I):233-243.

30. Cosner ME, Raubeson LA, Jansen RK: Chloroplast DNA rearrangements in Campanulaceae: phylogenetic utility of highly rearranged genomes. BMC Evol Biol 2004, 4(I):27.

31. Milligan BG, Hampton JN, Palmer JD: Dispersed repeats and structural reorganization in subclover chloroplast DNA. Mol Biol Evol 1989, 6(4):355-368.

32. Keller MD, Selvin RC, Claus W, Guillard RRL: Media for the culture of oceanic ultraphytoplankton. J Phycol 1987, 23:633-638.

33. Altschul SF, Gish W, Miller W, Myers EW, Lipman DJ: Basic local alignment search tool. J Mol Biol 1990, 215(3):403-4I0.

34. O'Brien EA, Badidi E, Barbasiewicz A, deSousa C, Lang BF, Burger G: GOBASE - a database of mitochondrial and chloroplast information. Nucleic Acids Res 2003, 3 I(I): 176-178.

35. Schwartz S, Zhang Z, Frazer KA, Smit A, Riemer C, Bouck J, Gibbs R, Hardison R, Miller W: PipMaker - a web server for aligning two genomic DNA sequences. Genome Res 2000, I0(4):577-586.

36. Kurtz S, Choudhuri JV, Ohlebusch E, Schleiermacher C, Stoye J, Giegerich R: REPuter: the manifold applications of repeat analysis on a genomic scale. Nucleic Acids Res 200I, 29(22):4633-4642. 
37. Volfovsky N, Haas BJ, Salzberg SL: A clustering method for repeat analysis in DNA sequences. Genome Biol 200I, 2(8): Research0027.

38. Hall TA: BioEdit: a user-friendly biological sequence alignment editor and analysis program for Windows 95/98/NT. Nucl Acids Symp Ser 1999, 41:95-98.

39. Rice P, Longden I, Bleasby A: EMBOSS: the European Molecular Biology Open Software Suite. Trends Genet 2000, 16(6):276-277.

40. The GNU Image Manipulation Program [http:// www.gimp.org]

41. The Vmatch large scale analysis software [http:// www.vmatch.de]

42. Choudhuri JV, Schleiermacher C, Kurtz S, Giegerich R: GenAlyzer: interactive visualization of sequence similarities between entire genomes. Bioinformatics 2004, 20(12): 1964- 1965.

43. Tesler G: GRIMM: genome rearrangements web server. Bioinformatics 2002, I8(3):492-493.

44. Michel F, Westhof E: Modelling of the three-dimensional architecture of group I catalytic introns based on comparative sequence analysis. J Mol Biol 1990, 2 I 6(3):585-610.

Publish with Bio Med Central and every scientist can read your work free of charge

"BioMed Central will be the most significant development for disseminating the results of biomedical research in our lifetime. "

Sir Paul Nurse, Cancer Research UK

Your research papers will be:

- available free of charge to the entire biomedical community

- peer reviewed and published immediately upon acceptance

- cited in PubMed and archived on PubMed Central

- yours - you keep the copyright

Submit your manuscript here:

http://www.biomedcentral.com/info/publishing_adv.asp
BioMedcentral 